\title{
Oral Health Attitude and Status of Turkish Dentistry Students
}

\author{
Türk Diş Hekimliği Öğrencilerinin Ağız Sağlı̆ğ Durum ve Tutumları
}

Tamara Pelin GÜNDOĞDU ÖZDAL ${ }^{1} @$, Gülsüm DURUK ${ }^{2} @$

$\ddot{O} z$

Amaç: Diş Hekimliği Fakültesi'nde okuyan öğrencilerin kendi ağız ve diş sağlıklarının değerlendirilmesi bu çalışmanın amacıdır. Bunun sonucunda toplum ağız ve diş sağlığını etkileyecek olan geleceğin diş hekimlerine, kişisel sağlıklarını korumaları için etkili eğitim yöntemlerini geliştirecek fikirler üretilecektir.

Materyal ve Metot: İnönü Üniversitesi Diş Hekimliği Fakültesi'nde eğitim gören 200 öğrenciye sosyodemografik, ağı diş sağlığı, beslenme düzeniyle ilişsili sorular içeren anket verilmiş, ardından her öğrencinin oral muayenesi yapılarak değerlendirilmiştir.

Bulgular: Öğrencilerin sınıf dereceleri arttıkça genel olarak ağı ve diş sağlığına ve beslenmeye önem verdikleri ortaya çıkmıştır. Eğitime başladıkları zamandan itibaren restoratif tedavi yaptırma oranı artmış, diş çürüğü sayısı azalmıştır.

Sonuçlar: Diş hekimliği öğrencilerinin toplumu eğitecek ve etkileyecek bireyler olduğu düşünüldüğünde kişisel sağl1k ve bakımlarına daha fazla dikkat etmeleri gerekmektedir. Dolayısıyla öğrencilere edindirilen doğru ağız ve diş sağlığı alışkanlığı tüm toplumun sağlığını etkileyecektir.

Anahtar Kelimeler: Diş hekimliği öğrencileri, ağız sağlığı, bilinç

\section{Abstract}

Objective: The aim of this study is to evaluate the oral and dental health of students studying at the Faculty of Dentistry. As a result, the ideas to improve effective training methods for future dentists who will have impact on oral and dental health of the society will be developed.

Methods: A survey including sociodemographic, oral and dental health-associated questions was conducted with 200 students who were studying at Faculty of Dentistry of Inonu

Tamara Pelin Gündogdu Özdal (四)

${ }^{1}$ Research Assistant, Department of Pediatric Dentistry, Faculty of Dentistry, Inonu University, Malatya,Turkey

İn̈nü Üniversitesi Diş Hekimliği Fakültesi Pedodonti AD. Malatya, TURKEY Phone:+90 553.713.0201

e-mail:tamarapelin@hotmail.com

Gülsüm Duruk

2 Assistant Professor Dr., Department of Pediatric Dentistry, Faculty of Dentistry, Inonu University, Malatya,Turkey

Submitted / Gönderilme: 07.05.2019

Accepted/Kabul: 25.06.2019
University and subsequently, dental examination of each student was performed and evaluated.

Results: It has been noted that students generally give importance to oral and dental health and nutrition as their grade level increases. It is observed that since the beginning of their education, the rate of restorative treatment increased, and the number of tooth cavity is decreased.

Conclusions: Considering that dentistry students are individuals who will educate and influence the society, they need to pay more attention to their personal health and care. Therefore, the right oral and dental health practice acquired as a habit by students will affect the health of the entire society.

Keywords: Dental students, oral health behavior, oral health knowledge

\section{INTRODUCTION}

Attention of individuals to personal dental care is a process of self-awareness and determines the importance given to dental health services. This perception is subjective and varies from one person to another independently of existing reality. Thus, two individuals with the same oral health problem can evaluate their personal oral health status differently. $(1,2)$ Oral diseases are one of the most common problems in the world. Impaired oral health impacts the general condition and quality of life of individuals negatively. Therefore, dental diseases and the problems of dental tissues are considered as a real public health problem. One of the greatest challenges of increasing the oral health of the population of low socioeconomic level is observed to be the difficulty of providing education.(3) It was reported that adults experience difficulty in their daily life and disruptions in business life due to the tooth cavities.(4) Nevertheless, the young population, especially in developed countries, consists of individuals who pay more attention to oral hygiene.(5) The reasons behind the improvement in oral and dental health in developed countries have been stated as 
improved quality of life, having easy access to toothpaste and other products containing fluoride and promotion of their widespread use.(6) On the other hand, inadequate access to oral health services, lack of knowledge in oral care practices, and their consequent impact on the overall health pose a danger.(7)

Being healthy in terms of dental care significantly affects mental, physical and social well-being. As dental students are in contact with the majority of the population, they have an important role in influencing oral health of the society.(8) It forms an appropriate group to examine the oral health attitudes of dentist candidates who will work in order to develop oral health in the future. This project aims to evaluate the situation oral care attitude and awereness of dental students.

\section{METHODS}

A survey was conducted with all students from 1st grade to 5th grade of the Faculty of Dentistry of Inönü University located in Malatya province of Turkey. The Ethics Committe of Inonu University approved the protocol of this study (2019/01-19). Chi-square test was used for the statistical datas. At the end of the survey, dental examination of all students was conducted by a single person (TPGO). The attended students' data is given on table 1 .

Table 1. Data of the attended students

\begin{tabular}{|l|l|l|l|l|l|l|}
\hline Class & \multicolumn{2}{|l|}{ Total number } & \multicolumn{2}{l|}{ Female } & \multicolumn{2}{l|}{ Male } \\
\hline & $\mathrm{n}$ & $\%$ & $\mathrm{n}$ & $\%$ & $\mathrm{n}$ & $\%$ \\
\hline 1 & 50 & 25 & 35 & 70 & 15 & 30 \\
\hline 2 & 37 & 18.5 & 16 & 43.2 & 21 & 56.8 \\
\hline 3 & 33 & 16.5 & 19 & 57.5 & 14 & 42.5 \\
\hline 4 & 39 & 19.5 & 15 & 38.5 & 24 & 61.5 \\
\hline 5 & 41 & 20.5 & 15 & 36.6 & 26 & 63.4 \\
\hline Total & 200 & 100 & 100 & 100 & 100 & 100 \\
\hline
\end{tabular}

The survey (figure 1) consists of 3 parts:

1. Sociodemographic and general health assessment

\section{Dietary habits}

3. Oral care habits and oral health awareness

In the examination, DMFT (total decayed, filled, and missing teeth) and DMFS (surfaces of total decayed, filled, and missing teeth) (9), plaque and gingival indices (PI,GI) (10) occlusion degrees and overjet / overbite distance were evaluated.
During examination, disposable gloves and masks, mirrors, sond and air-water spray were used. Periodontal sond was utilized during periodontal examination.

\section{RESULT}

\section{Sociodemographic Data}

$50 \%$ are female and $50 \%$ are male of the total 200 students. It was found that the average age was $21.84 \pm 2.698$ (min:17,max: 38). The number of 1st Grade students was found to be 50 while the number of 2 nd Grade students was to be 37; the number of 3rd Grade students was 33; the number of 4th Grade students was found to be 39 and the number of 5 th Grade students was to be 41 .

It was noted that the mother of $20 \%$ of the students and the father of $9 \%$ of the students were illiterate. The mother of $20 \%$ of the students and the father of $9 \%$ of the students are illiterate. When information on the education level of mothers and fathers of the students were obtained, it was found out that mothers are primary school graduates with the highest percentage as $\% 37$, the percentage of students having a university graduate mother is $15.5 \%$. $(\mathrm{p}<0.05)$. The fathers are university graduates with the highest percentage as $36 \%(\mathrm{p}<0.05)$.

The average number of siblings was found as $3.7 \pm 1.9$ (min:0, max:14). $64.5 \%$ of the students live in a flat and $35.5 \%$ stay at a dormitory or a pension $(\mathrm{p}<0.05)$. Monthly the average amount of pocket money was identified as $€$ $556.7 \pm 87.3$.

When asked about the regularly used medications, it was learned that $0.05 \%$ of them use antidiabetic, $0.05 \%$ of them use antibiotics and $2.5 \%$ of them use antidepressants. When students were asked to evaluate their general personal medical condition, there was no statistically significant difference between the grades. Moreover, $15.5 \%$ of the students stated that their health status is very good, $66 \%$ of them stated as having good health, $18.5 \%$ of them stated as having average health status and none of the students indicated having a bad or very bad health condition $(p<0.01)$.

It was learned that $13.5 \%$ of the students were smoking. The highest smoking rate was observed among 4th grade students $(25.5 \%)$. The class with the highest rate of nonsmokers was observed as 3 rd grades $(6 \%)(p<0.05)$. 


\section{Dietary Habits}

$49 \%$ of the students stated that they eat their main meals breakfast, lunch, dinner) without skipping them. The highest rate of those who regularly eat their main meals was found in the 1 st grade $(54.0 \%) .58 \%$ of the 1 st grade students stated that they skip breakfast, while on average of $66 \%$ of the 4 th and 5th grade students stated that they skip lunch. As the grade of the students increases, the rate of regular nutrition decreases gradually $(p<0.05)$. It was found that the grade having the least regular diet was the 5 th grade $(41.5 \%)$.

Among all grades, $47.5 \%$ of the students has stated that they drink water during the meal; while the group drinking the lowest amount of water was to be the 1st grade (42\%), the group drinking the highest amount of water was found to be the 5th grade (53.3\%). Consumption of acidic drinks were found to be the highest in the 1st grade with $22 \%$ whereas it was found to be the lowest in the $5^{\text {th }}$ grade as $15.3 \%$ ( $\mathrm{p}>0.05)$.

\section{Oral Care Habits And Oral Health Awareness}

All grades were asked questions about their tooth-brushing habits, methods and frequency. The ratio of the individuals brushing their tooth two or more per day was found the highest in 5th grade, while the lowest ratio was found in the 1st grade. (figure 2)

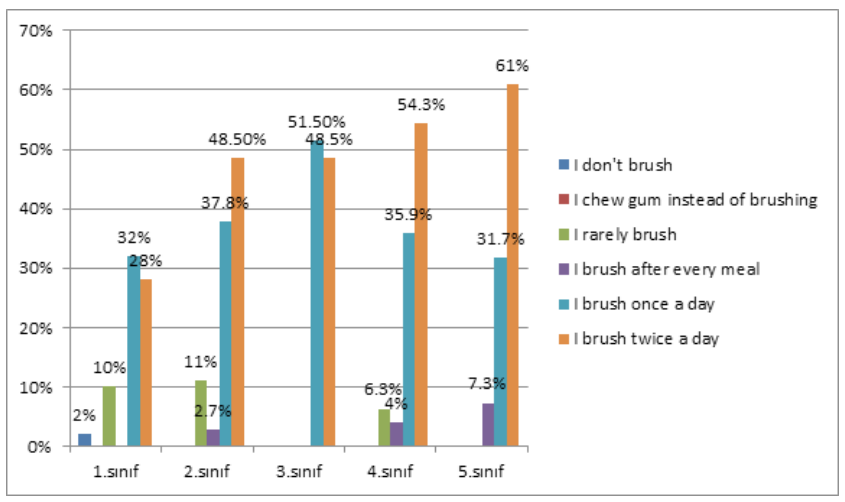

Fig 2. Tooth brushing habits of each class

It has been noted that the percentage of students who brushes only the front surface of their teeth is $2.7 \%$, the percentage of students who brushes all teeth surfaces including tongue is $97.5 \%$ among the 1st grade students. It has been highlighted that the percentage of students brushing all tooth surfaces along with tongue is $100 \%$ in all other grades. When the information obtained about the technique of using the toothbrush, it was found that the percentage of brushing the teeth from the gingiva to the tooth was $82 \%$, from the tooth to the gingiva was $8 \%$ and with the horizontal movements was $10 \%$ among the 1 st grade students $(p>0.05)$. All students stated that they brush their teeth from the gingiva to the tooth except for the freshmen. Regarding the question about frequency of the floss usage, answers revealed no significant difference between the grades. While $10 \%$ of the students stated that they use dental floss every day, $31 \%$ stated that they use 2-3 times in a week ( $>0.05)$. The percentage of those who do not use dental floss was found to be $36 \%$. The floss usage ratio was found to be significantly higher in female students than in male students $(p<0.05)$. While $16 \%$ of female students use dental floss every day, this rate is $4 \%$ for male students. The percentage of using no dental floss is $21 \%$ for female students and $51 \%$ for male students. While $7 \%$ of all female students use mouthwash every day, $4 \%$ of male students use it daily. $66 \%$ of male students do not use mouthwash, whereas this percentage is found to be $59 \%$ for female students ( $>0.05$ ). For the question of "Have you ever had a dental treatment?", $84.5 \%$ of all students answered yes, and while $10 \%$ of female students have never visited a dentist, this percentage is found to be $21 \%$ for male students $(\mathrm{p}<0.05)$.

$12 \%$ of the female students stated that they have tartar whereas this percentage was found to be $23 \%$ for male students $(p<0.05) .47 \%$ of the female students said that they have tooth cavity as this percentage was found to be $51 \%$ for male students ( $>0.05)$. While the percentage of female students who indicated that they have dental fillings was $68 \%$, this percentage was found as $57 \%$ for male students $(\mathrm{p}>0.05)$.

\section{The Findings From The Examination Of The Oral Cavity}

No significant difference was found in DMFT and DMFS scores between grades $(p>0.05)$. The group with the highest average number of filled teeth was $3^{\text {rd }}$ 
Table 2. Intraoral examination results

\begin{tabular}{|l|l|l|l|l|l|l|l|l|}
\hline Class & DMFT & DMFS & PI & GI & $\begin{array}{l}\text { Dental } \\
\text { Fillings (n) }\end{array}$ & $\begin{array}{l}\text { Decayed teeth } \\
(\mathbf{n})\end{array}$ & Over-jet & Over-bite \\
\hline 1 & $0.12 \pm 0.12$ & $0.06 \pm 0.05$ & $0.60 \pm 0.65$ & $0.32 \pm 0.48$ & $1.80 \pm 2.48$ & $2.61 \pm 1.67$ & $1.24 \pm 1.01$ & $1.59 \pm 1.17$ \\
\hline 2 & $0.16 \pm 0.15$ & $0.05 \pm 0.05$ & $0.51 \pm 0.61$ & $0.32 \pm 0.53$ & $2.43 \pm 3.27$ & $1.89 \pm 2.03$ & $1.46 \pm 1.35$ & $1.54 \pm 1.64$ \\
\hline 3 & $0.21 \pm 0.12$ & $0.06 \pm 0.05$ & $0.79 \pm 0.82$ & $0.73 \pm 0.88$ & $3.58 \pm 3.35$ & $2.15 \pm 2.25$ & $0.73 \pm 1.32$ & $0.73 \pm 1.32$ \\
\hline 4 & $0.12 \pm 0.08$ & $0.04 \pm 0.03$ & $0.49 \pm 0.68$ & $0.49 \pm 0.72$ & $1.69 \pm 1.91$ & $1.51 \pm 1.86$ & $0.82 \pm 1.41$ & $0.51 \pm 0.97$ \\
\hline 5 & $0.16 \pm 0.11$ & $0.04 \pm 0.03$ & $0.34 \pm 0.48$ & $0.37 \pm 0.58$ & $3.20 \pm 3.01$ & $0.53 \pm 1.21$ & $1.27 \pm 1.31$ & $1.07 \pm 0.91$ \\
\hline Total & $0.17 \pm 0.12$ & $0.53 \pm 0.51$ & $0.54 \pm 0.66$ & $0.43 \pm 0.65$ & $2.48 \pm 2.88$ & $1.86 \pm 2.24$ & $1.12 \pm 1.27$ & $1.12 \pm 1.30$ \\
\hline
\end{tabular}

grade students with the average of $3.58 \pm 3.35$. This was

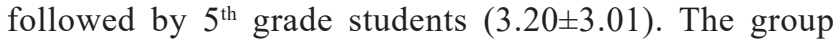
with the lowest number of decayed teeth was in the $5^{\text {th }}$ grade $(0.53 \pm 1.21)$.

The number of decayed teeth is $1.60 \pm 2.05$ for female students and $2.1 \pm 2.40$ for male students. While the number of filled teeth is $2.93 \pm 3.05$ for female students, it is $2.02 \pm 2.64$ for male students.

Average PI was found as $0.54 \pm 0.66$. Students with the lowest PI were the $5^{\text {th }}$ grade students $(0.34 \pm 0.48)$. No significant difference was identified between the groups $(\mathrm{p}>0.05)$. While the average PI for female students was $0.3 \pm 0.54$, this rate was found as $0.77 \pm 0.69$ for male students. Average GI was identified as $0.43 \pm 0.65$ in the entire faculty. While average GI of female students was $0.24 \pm 0.49$, it was $0.62 \pm 0.74$ for male students. (table 2) The different letters for each column indicate that the mean values are significantly different between the groups $(\mathrm{p}<0.05)$

\section{DISCUSSION}

\section{Sociodemographic and General Health Assessment}

The number of female and male students are equal in our faculty. In other studies, the ratio of female students was found to be higher than that of male students.(11) Cortes et al. indicate that the proportion of female students constitutes $70 \%$ of all students.(12) It was noted that the average age was 21.84 in our study. The average age was found similar with the Faculty of Dentistry at Barcelona.(13)

The mother of $20 \%$ of the students and the father of $9 \%$ of the students are illiterate. The parental education level in our study was significantly lower than the study conducted by Rodrigo J. et al. in New Zealand. In their study, it was noted that father of $67.6 \%$ of the students and the mother of $51.4 \%$ of the students have graduate and postgraduate degree.(14)
Monthly average pocket money was found to be 556.7 TL equal to $42 \%$ of the minimum wage level enacted at the time of the study. It has been highlighted that students have financial difficulties considering the average number of siblings which is $3.73 \pm 1.96$

While the dietary habit which is essential for the protection of the body defense system is the most appropriate in the 1st grade students, the rate of skipping a meal and having irregular eating habit have increased in the upper grades with the start of clinical internships and the increase in the course load. However, the daily water intake increased and the consumption of acidic drinks like coke decreased as the nutritional awareness increases.

It is stated that $28 \%$ of the 1 st grade students and $61 \%$ of 5 th grade students brush their teeth twice a day. In other studies, $74 \%$ of the students brush their teeth twice a day. (14)

It is seen that routine tooth brushing has become a habit as of the 3rd grade where dentistry courses are intensively initiated. It has been found that the percentage of toothbrushing after each meal is $15.3 \%$ in the 4 th grade and $7.2 \%$ in the 5 th grade. It was highlighted that $89 \%$ of the students in a similar study conducted in Casablanka ${ }^{13}$ and $74.1 \%$ of the students in a study conducted in Ankara brush their teeth twice or more in a day.(15) In our faculty, tooth brushing percentage of students $(\% 53)$ is found significantly low compared to abovementioned results

In our study, the percentages of daily floss and mouthwash were $10 \%$ and $11 \%$ respectively and these results were significantly lower than exemplary studies. These rates were found as $31 \%$ and $13 \%$ respectively in a study conducted by Peker et al.(16) In other study it was found that $16 \%$ of the students floss their teeth every day, $55 \%$ of the students use mouthwash.(17)

Although there was no significant difference identified in DMFT and DMFS scores among the grades, the group 
with the lowest number of decayed teeth was found in the 5 th grade. It has revealed that the oral health awareness of the students has increased as they started to the faculty and they preferred the treatment for their decayed teeth. The fact that female students have less decayed tooth, gingival and plaque indices than male students is considered to more relevant the oral care.

\section{CONCLUSIONS}

The faculties of dentistry are generally known as faculties that require high costs. It may be appropriate to rise the amount of scholarships provided to the students studying in these faculties.

Establishing a dietary habit is essential for a student studying in the Faculty of Dentistry. Considering the physical fatigue of students, particularly those undergoing a clinical internship, skipping a meal is upsetting.

Although oral care is regulated with the education in the faculty, these habits are still inappropriate. In order to make it more effective, it should be emphasized during the courses that the personal care of the students is also a part of dentistry and with regular examinations, students should be encouraged to undergo their treatments.

\section{ACKNOWLEDGEMENTS}

Part of this study was presented in a poster presentation at 21st Congress of the Balkan Stomatological Society BaSS. PP-59. May 12-15, 2016. Banja Luka, B\&H.

\section{REFERENCES}

1. Al-Wahadni AM . Al-Omiri MK. Kawamura M. Differences in self-reported oral health behavior between dental students and dental technology/dental hygiene students in Jordan. J Oral Sci.2004 Sep;46:191-197.

2. Sharda AJ. Shetty S. A comparative study of oral health knowledge. attitude and behaviour of first and final year dental students of Udaipur city. Rajasthan. India. Int J Dent Hyg.2008 Nov;6:347-353.

3. Atchison KA. Gift HC. Perceived oral health in a diverse sample. Adv Dent Res 1997; 11: 272-80.

4. Gift HC. Oral health outcomes research: Challenges and opportunities. In: Slade GD (eds).Measuring Oral Health and Quality of Life. Chapel Hill. NC: University of North Carolina. 1997.

5. Downer MC. The improving oral health of United Kingdom adults and prospects for the future. British Dental Journal. 1991; 23: 154-158.

6. Bratthall D. Hansel-Petersson G. Sundberg H. Reasons for the caries decline: what do the experts believe? European Journal of Oral Science. 1996; 104: 416 - 422.

7. Nadanovsky P. Sheiham A. Relative contribution of dental services to changes in caries level of 12-yearold children in 18 industrialized countries in the 1970s and the early 1980s. Community Dentistry Oral Epidemiology. 1995; 23: 331339.

8. Gallagher EB. Moody PM. Dentists and the oral health behavior of patients: A sociological perspective. J Behav Med. 1981;4: 283-95.

9. World Health Organization. Oral health surveys: basic methods. World Health Organization; 2013.

10. Löe, H., \& Silness, J. (1963). Periodontal disease in pregnancy I. Prevalence and severity. Acta odontologica scandinavica, 21(6), 533-551.

11. Malbrunot X. Socio-economic situation of students in neurodontology in Clermont-Ferrand in 1991/1992 . [Thesis dental surgery]. Clermont-Ferrand. 1993.

12. Cortes FJ. Nevot C. Roman JM. Cuenca E. The evolution of dental health in dental students at the University of Barcelona. J Dent Educ.2002 Oct; 66:1203-1208.

13. Mariño. Rodrigo J.. et al. "Sociodemographic backgrounds and career decisions of Australian and New Zealand dental students." Journal of Dental Education. 2006;70: 169-178.

14. Ganss C, Schlueter N, Preiss S, Klimek J. Tooth brushing habits in uninstructed adult-frequency, technique, duration and force. Clin Oral Invest. 2009;13:203-208.

15. Rimaoui S. Rahmaoui M. Hamza M. Bennani A. Oral health of dental students in casablanca. Int J Dentistry Oral Sci. 2017;4:557-564.

16. Peker I. Alkurt MT. Oral health attitudes and behavior among a group of turkish dental students. Eur J Dent. 2009 Jan;3:2431.

17. Neeraja, R., Kayalvizhi, G., \& Sangeetha, P. Oral health attitudes and behavior among a group of dental students in Bangalore, India. European journal of dentistry. 2011;5:163. 
Class:

1. Name-Surname

2. Age

3. Sex

4. Number of siblings

5. Mother's education status
$\square$ Illiterate $\quad \square$ Primary school $\square$ Middle school
$\square$ Highschool $\square$ Graduate $\quad \square$ Postgraduate

6. What's your mother's job?...........................

7. Father's education status

$\square$ Illiterate $\quad \square$ Primary school $\square$ Middle school
$\square$ Highschool $\square$ Graduate $\quad \square$ Postgraduate

8. What's your father's job?

9. What is your average monthly expenditure?

10. Where do you live in?

$\square$ Home $\quad \square$ Dormitory/pension

11. Do you take any drug regularly?

If yes, what is it for?

12. How do you rate your health?

$\square$ Very good $\square$ Good $\square$ Average $\square$ Bad

13. Do you smoke? $\square$ Yes $\square$ No

14. Which meal do you skip the most?
Breakfast $\square$ Lunch $\square$ Dinner

15. Which drink do you prefer in during meal?

Water $\square$ Juice $\square$ Coke $\square$ Ayran $\square$ Others

16. How is your toothbrushing habit?

$\square$ I don't brush

I chew gum instead of brushing I rarely brush

$\square$ I brush after every meal I brush once a day
I brush twice a day

17. How do you brush your teeth?

Only the front surface

All teeth surfaces including tongue

Which technique do you prefer while toothbrushing?

From gingiva to teeth

From teeth to gingiva

Horizontally

18. Do you use dental floss?

Everyday

2-3 times in a week

2-3 times in a month

Never

19. Do you use mouth rinse solution?

Everyday

$\square$ 2-3 times in a week

2-3 times in a month

Never

20. Have you ever get dental treatment?

Yes $\square$ No

21. Which ones do you have?

Cavity

Missing tooth

Dental filling

Tartar

Fig 1. Sample of survey 